\title{
Ewa Poplawska*
}

\section{Preamble to the Constitution as an Expression of the New Axiology of the Republic of Poland}

\begin{abstract}
If we realize that in the first constitutional laws of modern constitutionalism (such as the Constitution of the USA of 1787, the Declaration of the Rights of Man and of the Citizen, the Polish Constitution of 3 May 1791 and the French Constitution of 3 September 1791), the contents of the preambles corresponded to contemporary chapters defining the principles of the systems of state government, while the opening chapter of the Polish Constitution of April 2, 1997 includes 29 articles, a question arises whether it was necessary to precede that Constitution with a preamble. ${ }^{1}$ Introductions to constitutions are part of the Polish systemic tradition: they featured in the Constitution of 1791, as well as in the so-called March Constitution of 1921, the Constitution of the Polish People's Republic of 1952 and the so-called Small Constitution of 1992, whereas the so-called April Constitution of 1935 did not have one.

Like those of other states, the major contents of the Preamble to the Constitution include a solemn proclamation of those principles and assumptions that its makers found particularly important in light of the state's history and contemporaneous situation. Setting these out explicitly was assumed to further the goal of integrating consecutive generations around a certain system of values as well as legitimising the system of government that was thereby established. ${ }^{2}$ This is why the Preamble indicates the entity who acts as the constitutional legislator (pouvoir constituant) as "the Polish Nation-all citizens of the Republic", describes the Constitution itself as the "the basic law for the State", characterizes the historical context in which the fundamental law was adopted andmost significantly-lists all the basic goals of the Polish State and the fundamental principles underlying the fundamental law.

The reader may find it striking that the Preamble contents largely overlap, or at least are not coordinated with, the wording of provisions of the first chapter, entitled "The Republic". This chapter is, as we have mentioned, very long and-as the title suggests-not only does it list the classic principles of the state government system, but it also gives quite an exhaustive description of the Polish national community in all its complexity (including the state's main tasks and symbols, but also, among other things, references to the institutions of civil society, the definition of marriage enjoying the protection of the state, the duty to take care of war invalids, etc.). ${ }^{3}$
\end{abstract}

Keyword: Polish constitution, National Assembly classic principles, preamble, European Union, subsidiarity

${ }^{*}$ Ph.D., Institute of Legal Studies of the Polish Academy of Sciences, Nowy Świat 72, 00-330 Warszawa, Poland.

E-mail: epoplawska@poczta.onet.pl

1 Sarnecki, P.: Systematyka konstytucji [Systematics of the Constitution]. In: Trzciński, J. (ed.): Charakter i struktura norm konstytucji [Character and Structure of Norms of the Constitution]. Warsaw, 1997, 25.

2 Garlicki, L.: Commentary on the Introduction to the Polish Constitution. In: Garlicki, L. (ed.): Konstytucja Rzeczypospolitej Polskiej [Constitution of the Republic of Poland]. Vol. V, Warsaw, $2008,2$.

${ }^{3}$ Gebethner, S.: Rzeczpospolita w świetle postanowień rozdziału pierwszego Konstytucji z 1997 roku [The Republic in the light of provisions of the first chapter of the Polish Constitution]. In: Podstawowe pojęcia pierwszego rozdziatu Konstytucji RP [Basic Notions in the First Chapter of the Polish Constitution]. Katowice, 2000, 14-16. 
It is something of a paradox that because of the moment and circumstances of adoption, the Preamble is more a device supporting and crowning the fundamental law than an introduction to it. ${ }^{4}$ This results from the fact that, despite the intentions the National Assembly previously adopted, according to which there was to be no introduction, at the final stage of work on the Constitution (at the end of 1996) a decision was made to include an introduction which was to determine finally the ideological character of the fundamental law. Out of the seven constitutional bills submitted to the National Assembly, four had introductions, while three did not. Although in the course of work the idea of adding a preamble was not excluded, the vast regulation of Chapter I originally tipped the scales against a preamble. The eventual decision to add an introduction at the final stage of work on the Constitution was taken on strictly political grounds. In an attempt to get the supermajority in the National Assembly required to adopted the constitution (2/3) and then passage in the national referendum, a decision was made to include a Preamble with a denominatio Dei and references to axiology similar to the social teaching of the church.

The coalition of the centre-left parties (SLD, PSL, UW, UP) that reached agreement as to the text of the Constitution hoped to broaden approval among members of the Parliament and, later on, the Poles voting in a referendum, to include right-wing circles by means unequivocally anchoring the fundamental law in a system of values close to Christian democracy. The plan failed, because the opposition did not change its hostile attitude despite the inclusion of a preamble.

Eight drafts of the Preamble were submitted, and of these the version Tadeusz Mazowiecki had promoted, prepared by Catholic intellectual and activist Stefan Wilkanowicz, was chosen. The somewhat hasty preparation of the Preamble and failure to correct the provisions of the first chapter after the Preamble had been adopted caused the existing repetitions and inconsistencies.

The introduction is written in a particularly solemn style, which is typical of preambles in general. Although doubts as to the normative character of the introduction, or at least its portions capable of direct application, currently seem to have been positively settled by the Constitutional Court, at the time the Constitution was adopted the situation was less unequivocal and the views of Polish legal scholars and commentators diverged. One should not be surprised that devotion to traditional, pompous and sometimes not sufficiently clear language prevailed over care for clarity of the language of the law.

The first problem caused by the Preamble concerns the definition of the Polish Nation as the constitution-maker-the entity that establishes the Constitution "as the basic law for the State". In this context, the Preamble further defines the Polish Nation as "all citizens of the Republic", therefore a political and not an ethnic nation. But at the same time it makes reference to being "bound in community with our compatriots dispersed throughout the world", therefore not ignoring the other definition of a nation.

The National Assembly decided to recognise the existing division of Polish citizens by referring to both "those who believe in God as the source of truth, justice, good and beauty" and "those not sharing such faith but respecting those universal values as arising from other sources". Members of both categories are treated as "equal in rights and obligations towards the common good-Poland". The authors' intention was to stress the universal character of the highest values on which the Polish national community is founded: truth, justice,

${ }^{4}$ Complak, K. In: Boć, J. (ed.): Konstytucje Rzeczypospolitej oraz komentarz do Konstytucji RP z $1997 r$. [Polish Constitutions and Commentary on the 1997 Constitution]. Wrocław, 1998, 13. 
goodness and beauty, even though there are various sources from which different persons assume their origin. A more down-to-earth argument for choosing the expression was the intention to find a formula to replace the invocation of God, which was firmly demanded by right-wing and Catholic circles. Although the introduction also refers to the "Christian heritage of the Nation", these expressions did not convince those opponents, who did not consider these a worthy substitute for the desired express reference to God ("In the name of God Almighty..." was included in Polish constitutions of 1791 and 1921). These references were also criticised by supporters of consistent secularisation of the Constitution. Paradoxically, the dualist formula, judged as moderately successful in Poland, was taken into consideration when the Convention on reform of the European Union worked on the Preamble to the Constitutional Treaty.

References to a supernatural being are not references to a specific religion, but relate to all faiths especially in the context of recent events that polarized the Polish community after the presidential plane crash, when reflecting on the expediency of the double definition of members of the Nation in the Constitution, one cannot lose sight of its basic meaning. The Constitution clearly emphasises the shared highest values, while realistically stating the different ideological backgrounds of citizens. It does the same when it mentions "our responsibility before God or our own consciences", which is to accompany the establishment of the Constitution.

From that formulation one can draw an important interpretative conclusion as to the nature of the Polish state. Firstly, it excludes both transformation into a religious state and into a radically atheist one. (The details of the relationship between the state and religious organizations is regulated by Art. 25 of Chapter I and Art. 48 and 53 of Chapter II, which is devoted to the status of an individual.) Secondly, it introduces into the text of the fundamental law a reference to transcendental, supernatural values, which fits well with the definition of "the inherent and inalienable dignity of the person" as "a source of freedoms and rights of persons and citizens" (Art. 30). Thus, the Preamble initiates the introduction of natural law into the Polish fundamental law and gives it a binding character.

It is also in the classical part of the introduction, which refers to the history and place of the state in the contemporary world, that one can find important axiological provisions, to which the Constitutional Court has often referred in its judgments. The makers of the Constitution leave no doubt as to which periods of Polish history and corresponding systemic solutions they perceive as positive (for example, "struggle for independence achieved at great sacrifice", "the best traditions of the First and the Second Republic") and which ones they condemn ("bitter experiences of the times when fundamental freedoms and human rights were violated in our Homeland").

In a way unprecedented in Polish constitutional history, the fundamental law of 1997 expresses the State's attitude towards its international surroundings. Constitution makers, in light of the Preamble, declare that they are "aware of the need for cooperation with all countries for the good of the Human Family". In the legal sphere, pursuant to Art. 9 ("The Republic of Poland shall respect international law binding upon it."), there is proclaimed as a principle a general favourable attitude of Polish law towards international law, which is then concretised by way of a detailed regulation on the place of international agreements in the domestic legal order and through openness to integration processes. Not only did the Constitution provide for the possibility of transferring the powers of State authorities as to some matters to an international organization or body, together with a specific procedure for expressing consent to ratification of an agreement upon such a transfer, but it also anticipated the inclusion in the national legal order of legal instruments with an integrative character enacted by such an organization. 
Due to the scope and abundance of constitutional provisions that form the grounds for the international cooperation of the Republic of Poland, they can be considered as an element of axiology of the fundamental law. Unlike "constitutional values", this axiological choice in the Constitution is realized by way of sub-constitutional instruments (among others, extensive amendments to laws because of the need to harmonize them with EU law before accession, and now implementing directives), and expressed in the case law of the Constitutional Court. In its judgment assessing the conformity of the Accession Treaty with the Constitution, the Court referred to the constitutional principles quoted in the Preamble, such as democracy, respect for rights of the individual, cooperation between the public powers, social dialogue and the principle of subsidiarity, and pointed out that these principles belong at the same time to "fundamental assumptions of functioning of the European Communities and the European Union" (judgment K 18/04). It was on the axiological aspects that it grounded, among other things, its convictions about the lack of discrepancies between the Accession Treaty and the Polish Constitution.

The Preamble identifies the basic values to be realised by the Polish State. It mentions the desire to "guarantee the rights of the citizens for all time" and ensure "diligence and efficiency in the work of public bodies". The principles on which-according to the Preamble-"the basic law for the State", that is, the constitutional provisions, are to be based occupy a special place. It also refer to "respect for freedom and justice", "cooperation between the public powers", "social dialogue" and "the principle of subsidiarity in the strengthening the powers of citizens and their communities". It is clear from the context that there can be no doubt that the constitutional legislator intended that those applying the fundamental law be guided by the above principles. The first is developed in detail in the "articled" part of the Constitution. The second further defines the principle of the separation and balance of powers from Art. 10 and clarifies that the system of government in Poland corresponds to the parliamentary model. "Social dialogue" should be understood more broadly than just in the context of a social market economy, as a principle of the socioeconomic system of the Republic of Poland (Art. 20), where the term is used again.

The last principle, that of subsidiarity, deserves special attention, because it is the focus of problems relating to the normative character of the Preamble. Although this principle, too, is reflected and concretised in detailed constitutional provisions, it is not clearly repeated there, nor, all the more so, is it defined, which arouses doubts in light of Poles' slight familiarity with (or even the prevailing misunderstanding of) this principle.

While the principle of subsidiarity is a novel solution as far as Polish constitutional provisions are concerned, it has already served as a useful point of reference and a general guideline in the political and constitutional transformations that Poland has been going through in recent years. It offers an exceptionally pertinent answer to a fundamental question about the desired extent and tasks of State authority. While in search of the model of the State and its functions that best corresponds with the needs of post-Communist society, one could hardly accept without any greater objections the model of the welfare State which-as shown by recent West-European experience-has failed due to its overdevelopment of the administration and impoverishment of the public sector and the related growing passivity of the citizens. What seems just as ill-suited to the social situation of Poland is another model initially thought to be an effective remedy against the negative social phenomena inherited from the former system: that is, the model of a liberal State in the classic sense, with the State's organizational functions restricted to the minimum. 
According to the principle of subsidiarity, the chief function of power is to satisfy the needs of its subordinate communities or persons who shape their fates independently and bear the related responsibility but are incapable of full development. The aims and tasks of power should not extend beyond those of its subordinate individuals or groups. What justifies the existence of power is the lack of self-sufficiency on the part of those individuals and groups. Therefore, the role of power is secondary and auxiliary as it is nothing but a means to the achievement of aims by individuals and communities.

The idea of subsidiarity-a specific "common sense" principle relating to the nature of all social organizations-has been known for many ages now and can be found repeatedly in the history of philosophy and in political thought. Subsidiarity's roots lie in Aristotelian political science and Thomist doctrine and philosophy. In the former, it appears as a principle of justice implicit in the notion that an association is not an end in itself but serves to help participants in the association to help themselves. This has been recognised in that since in large organizations the process of decision-making is more remote from the initiative of most of the many members who will carry out the decision, the same principle requires that larger associations should not assume functions that can be performed efficiently by smaller associations. ${ }^{5}$ In the Thomist context, it not only forms part of the Thomist notions of hierarchy and order but is also to be found in the notion of social and rational collaboration and the diversity of individual and collective capacities essential to such collaboration. ${ }^{6}$

However, Wilhelm Emmanuel von Ketteler gave the subsidiary principle its name only quite recently, in 1862 in "Freiheit, Autoritaet und Kirche", with respect to Germany and Switzerland.7 Since the 1930s, the social teaching of the Catholic Church, which related that principle to the philosophy of personalism, has made an important contribution to the conceptual development of the principle of subsidiarity. ${ }^{8}$

Until recently, subsidiarity was not a familiar part of the contemporary legal lexicon. That it has become so is largely due to controversy within the European Community over the terms on which it should progress towards some form of European Union. It has been employed in the debates over the division of competences between the Community (and then the Union) and its Member States. That process eventually resulted in a statement of the principle being incorporated in the European Community Treaty (Art. 3b) as amended by the Treaty on European Union (Maastricht) 1992, and then clarified in the Protocol on the Application of the Principle of Subsidiarity and Proportionality attached to the Amsterdam Treaty, 1997, approved and developed recently by the Lisbon Treaty of 2007. There, an attempt is made to allocate competence in terms of the criterion of achieving the objectives of the Community. Some have hailed it as a guiding principle for relations

5 Aristotle: The Politics. Translated by J.E.C. Welldon, New York, 1886.

${ }^{6}$ Aquinas, St. T.: On Kingship or the Governance of Rulers. In: On Politics and Ethics. Translated by Paul E. Sigmund, New York, 1988.

7 von Ketteler, W. E.: Freiheit, Autorität und Kirche. In: von Ketteler, W. E: Sämtliche Werke und Briefe. Mainz, 1877.

${ }^{8}$ Millon-Delsol, Ch.: Le principe de subsidiarité. Paris, 1993, 3-8; Millon-Delsol, C.: L'Etat subsidiaire. Paris, 1992, 18-84; Melchionni, M. G.: Subsidiarity from the historical perspective. In: Hrbek, R. (ed.): Die Anwendung des Subsidiaritätsprinzips in der Europäischen Union. Baden-Baden, 1995, 105-111. 
between the Union and its Member States; ${ }^{9}$ others regard it as a mere facade and doubt its value as a legal concept. ${ }^{10}$

Putting aside the specific application of the principle of subsidiarity with respect to the mechanisms of European integration, the mere fact of its introduction into the legal terminology contributed to its considerable popularity and theoretical development. As a principle of constitutional law, the principle of subsidiarity was among the subjects discussed at the 14th International Congress of Comparative Law held in Athens in August 1994. In a recapitulation of the work of 12 national reporters, Prof. John W. Bridge (University of Exeter, UK) stated that "subsidiarity is not generally found as an express principle of constitutional law, other than in the context of the European Union. But either the principle or the underlying concept from which the principle is derived is generally implicit or inherent in constitutional law and/or structures. In some cases the principle or concept has informed or is informing the constitution-making process. In others it is used as a tool of constitutional implementation and interpretation in relation to the allocation of decisionmaking power."”11

In accordance with the formulations of Catholic social science, the principle of subsidiarity is based on the assumption that man is the sole independent being. ${ }^{12}$ Just like man, who only seeks the community's help through organization of or participation in communities created by nature if he cannot perform his life tasks himself, and only to the extent necessary, any smaller or "inferior" community also only resorts to the help of larger or "superior" communities if it cannot perform its tasks as determined by the needs of all its members. Hence all "superior" communities are obliged to respect the rights of "inferior" communities, thus securing to them the possibility of performing their natural tasks.

The principle of subsidiarity can be reduced to the following two basic postulates in reference to the individual-community-State relation:

1. as much freedom as possible, as much collectivization as absolutely necessary;

2. as much society as possible, as much State as absolutely necessary.

Even if they have never been formulated as explicitly in official documents, these postulates formed the foundations of the Polish reform movement aimed at subversion of the totalitarian system.

The position of subsidiarity in the constitutional law follows from the principles of the organisation of socio-political life that can be educed from it. The first of these is the principle of organic construction of State community, in other words, of State pluralism. It postulates a multi-level organisation of society where, situated between individual and State, there are many varied intermediate communities: professional (trade unions and employers' unions), local (local governments), political (political parties) and cultural (associations). This conception sees the State as the supreme social organisation that coordinates and manages the whole of the social system, and not just something that controls

9 Delors, J.: Subsidiarité: défi du changement. Actes du colloque Jacques Delors. Maastricht, 1991; Constantinesco, V.: La subsidiarité comme principe constitutionnel de l'intégration européenne. Aussenwirtschaft, 1991, 439-459.

10 Dehousse, R.: Does Subsidiarity Really Matter? European University Institute of Florence Working Paper, LAW 92/32.

11 Bridge, J. W.: Subsidiarity as a Principle of Constitutional Law. General Report, International Academy of Comparative Law, XIV Congress, Athens, 31 July-6 August 1994, 30.

12 In particular, the encyclical Pope Pius XI: Quadragesimo Anno. 1931 and the encyclical Pope John XXIII: Mater et Magistra. 1961. 
an atomized society of individuals through its machine of coercion. What follows from the principle of pluralism are principles of self-government and of federation, a special case of national self-government.

Another principle of the organisation of social life that follows directly from subsidiarity is the principle of decentralisation of State authority. It consists of the State's renunciation of a part of its rights to inferior communities: national, local, professional organizations, unions of families, etc. The minimum postulate of decentralization is the separation of powers among the legislative, executive and judiciary, which prevents an accumulation of power with its demoralizing effect and the danger of abuse, and guarantees mutual supervision of the functionally separate elements of the State machine. Real decentralisation depends also on the structure and range of competences of administrative authorities, and in practice also on the professional level and moral standards of the administrative machine.

The third and probably most important principle to be educed from subsidiarity is the principle of democracy expressed by way of the real and not just formal participation of broad masses of society in government. For genuine democracy to be introduced, it is indispensable that all citizens be made equal and given the opportunity to participate in all spheres and manifestations of State activity.

To recapitulate the importance of the principle of subsidiarity, subjective freedom of individuals based on their equality before the law should be the basic source of law in a democratic State. This provides the foundations for social justice that meets the requirements of personal dignity and is based on the moral sense and free cooperation of community members. In a genuine democracy, the community of interests of the rulers and the ruled is derived not only from the rulers' awareness of being plenipotentiaries of the society but also from the two groups' profound inner moral bond that unites them in their journey towards the common good. ${ }^{13}$

The Republic of Poland is a unitary State where in the last 20 years a radical transformation of the political and socio-economic system took place and the autocratic totalitarian system controlled by the Communist party and the centrally planned economy were abandoned. For these reasons, manifestations of subsidiarity in Poland's constitutional system should be sought not precisely in the repartition of the powers of decision-making between the separate levels of the State machine but rather, and predominantly, in the radical and multi-plane subjectivisation of the society that resulted from the adopted principles of political pluralism and the free market.

These two principles follow from the profound revaluation of the mutual relations between individual, society and State that proceeds in the ideological sphere. The idea of subjection of the individual to the laws of history is replaced by that of inalienable human rights, the philosophy of collectivism by that of personalism and the idea of statism by the idea of civil society. ${ }^{14}$

Although the principle of subsidiarity was introduced expressly into Polish constitutional law only in the Constitution adopted in 1997, the whole of the reforms launched previously, which aimed at transforming the system from autocracy into liberal

13 See more: Strzeszewski, Cz.: Katolicka nauka spoleczna [Catholic Social Teaching]. Warsaw, $1985,508-521$.

${ }^{14}$ Sokolewicz, W.: Democracy, Rule of Law and Constitutionality in Post-Communist Society of Eastern Europe. Droit Polonais Contemporain-Polish Contemporary Law, (1990) 2, 5-6. 
democracy and at submission of the State to the rigours of law and of the Constitution above all, are of paramount importance to the position of individual in society and the State; they guarantee the rights and liberties of individuals and define the functions of the State with respect to society as a whole and to individuals as elements of that society.

The principle of subsidiarity was introduced into the Preamble of the Constitution as a principle underlying the whole legal system of the State, including-first and foremost-the Constitution. The principle of subsidiarity is mentioned in this context on a par with the principles of respect for freedom and justice, social dialogue and cooperation between the public powers. The National Assembly has not gone beyond "naming" the principle of subsidiarity in the Preamble, without elaborating on the topic in the main body of the Constitution. This does not seem to be a good solution, for the essence of the principle of subsidiarity remains rather obscure to society, while the most widespread interpretation that it has received limits subsidiarity to obliging authorities (the State) to provide unconditional assistance to individuals and communities in the name of "the common good". Describing the principle of subsidiarity as "strengthening the powers of citizens and their communities" will not prevent further interpretations of subsidiarity that ascribe, in the spirit of the welfare State, a rather narrow scope to the principle-indeed it may lead to such interpretations being perpetuated.

In formulating the preamble-as Tadeusz Mazowiecki, the MP who made the preamble motion, said-e was "oriented towards what actually is stipulated in the Constitution but what cannot be couched in the language of articles, but what can be put in terms of formulating a certain direction". ${ }^{15}$ Difficulty arriving at a proper definition of the principle of subsidiarity in terms of legal and constitutional language was actually invoked by members of the Constitutional Committee as an argument to abandon such an attempt. However, despite the evident difficulties that such a legislative task might involve, it would be a sign of excessive pessimism and restraint to claim, as deputy Jerzy Ciemniewski has, that "the principle of subsidiarity cannot be translated into a system of institutions" and that it is only the kind of "idea that such institutions may or may not be inspired by". ${ }^{16}$ Elaborating on the principle of subsidiarity in the Constitution seems to have been indispensable because while it has binding force, the public remains rather ill-informed as to its actual nature. Needless to say, for a principle to become an enforceable foundation of the social and constitutional order, it has to be understood by all those who are to adhere to it. Any possible misunderstandings concerning the term "subsidiarity" necessitate an educational effort. A special role should have been played here by an elaboration of the principle in the main body of the Constitution in the chapter dealing with the principles of the constitutional system in Poland.

Inclusion of the principle of subsidiarity in the Preamble and failure to fully elaborate on it in the main, so-called normative, part of the Constitution, might, in light of views sometimes presented by legal experts, have given rise to doubts as to the normative character of the principle. This, however, is not the case, for both the context in which the principle is invoked in the Preamble, as well as its normative content, i.e. the fact that the principle makes it possible for particular kinds of obligations to be specified for bodies that apply the Constitution, provide convincing grounds to recognize that the principle is unequivocally

15 See: proceedings of the session of the Subcommittee of general issues and introductory provisions of the Constitutional Committee, on 23 October 1996, 1.

16 Further page 10. 
normative in nature. The definitive answer to the question about the normative (binding) character of the Preamble is to be given by the judiciary, especially by the Constitutional Court. The principle of subsidiarity, even if it does not impose any specific and currently binding obligations on State authorities, indirectly sets down guidelines for legislation and for the application of the law.

Besides the reference to the principle of subsidiarity as a principle underlying the constitutional order of the State, in the Preamble elements of the principle of subsidiarity and provisions that have been inspired by it can be found in the following parts of the Constitution. Included among the constitutional principles, even before the definition of the Republic of Poland (as a "democratic State ruled by law and implementing the principles of social justice"), is the principle that "The Republic of Poland shall be the common good of all its citizens". Despite the general approval of the principle by members of the National Assembly, its sense and meaning, which goes beyond any ideological considerations, do not seem to be unambiguous. On the one hand, the quoted article is a tautology if the word "Republic" [Rzeczpospolita = literally: common good] is understood in its historical sense. On the other, if the article is meant to give special protection against any form of discrimination, it coincides with provisions to the same effect contained further on in the text. Their prominence in Art. 1 can be accounted for only by the intention to make them acquire the status of a constitutional principle, however, without creating much impact on the eventual application of the provisions, e.g. by adjudicating bodies. The prevalent view of members of the National Assembly was that describing the State as "the common good of all its citizens" would contribute towards developing an awareness of the natural link between the obligations of the State towards the citizens and the duties of the citizens, such as loyalty to, and the bearing of costs and burdens for the benefit of, their common good, the State (including taxes or military service). Such an interpretation seems to be confirmed by the reference to the "common good" in the Preamble: it appears in the context of the citizens' duties with respect to the State in the following passage: "[...] we, the Polish Nation-all citizens of the Republic, [...] equal in [our] rights and obligations towards the common good-Poland [...]".

A manifestation of the principle of subsidiarity in the Constitution is to be found in the formula in Art. 12 relating to civil society, based on the principles of liberty and pluralism with regard to public activity: "The Republic of Poland shall guarantee freedom of the creation and functioning of trade unions, socio-occupational organizations of farmers, societies, citizens' movements, other voluntary associations and foundations". The clause represents a step forward in comparison to the former formulation of the principle of political pluralism, for it also refers to civil society with its manifold forms of selforganization, and it is not restricted to guaranteeing freedom of formation and activity for political parties. In the chapter on "The freedoms, rights and obligations of persons and citizens", there are additional provisions regarding freedom of association, freedom of activity of national and ethnic minorities' organizations, religious communities, etc.

The constitutional formula on relations between the State and churches and religious unions (providing for their "autonomy and mutual independence of each in its own sphere, as well as their cooperation for the good of the person and the common benefit"-Art. 25 para. 3) is a reflection of an idea underlying the principle of subsidiarity, namely the idea of the separateness and preservation of specific methods of activity, as regards religious organisations and the State. The Constitution emphasises their mutual complementarity in the implementation of the overriding goal constituted by the good of the individual and the community. 
The constitutional principles also include provisions for participation of local authorities in the exercise of public power (Art. 16 para. 2: "Local government shall participate in the exercise of public power. The substantial part of public duties which local government is empowered to discharge shall be done in its own name and under its own responsibility"). This principle is further elaborated, in the spirit of subsidiarity, in other provisions of the Constitution dealing with local government, in particular those stipulating a presumption of the power of local government to perform public duties (Art. 163: "Local government shall discharge public functions that have not been reserved by the Constitution or statutes for other public authorities"), a presumption of the power of communes, the lowest tier of local government units, to perform the duties of local government (Art. 164 para. 3: "The commune shall discharge all local government functions that have not been reserved for other local government units"), and judicial protection of the autonomous nature of local government units (Art. 164, paragraph 2: "The autonomous nature of local government units is subject to judicial protection"). These provisions are, toutes proportions gardées, an equivalent of similar clauses in countries with a federal system of government, which recognize the powers of Ländern, cantons, states, etc. with regard to those duties that have not been enumeratively reserved for the federal authorities.

Separate regulations in the Constitution that have the force of constitutional principles relate to professional self-government. They provide for the creation by statute of selfgovernments for professions enjoying a high degree of public confidence, with a view to monitoring the proper practice of the professions within the limits, and for the protection, of the public interest (Art. 17 para. 1). They also permit other forms of self-government, provided they do not infringe upon the freedom of practicing a profession or impose restrictions upon the freedom to engage in economic activity (Art. 17 para. 2). The new formula highlights the public duties of self-governments within professions of public confidence, and at the same time makes the freedom of other forms of self-government dependent on respect for the fundamental freedoms of practicing a profession and engaging in economic activity.

The principle of subsidiarity also emerges in the newly introduced citizens' legislative initiative (under Art. 118 para. 2 of the Constitution; such an initiative can be launched by one hundred thousand citizens eligible to vote in Sejm elections). The citizens' initiative creates opportunities for organized groups of citizens, representing shared interests, to influence the shape of legislation. This provision, it seems, may contribute to giving a more tangible expression to the objectives held by various groups in society, and it may help such constituencies to organize themselves.

Another manifestation of the principle of subsidiarity, this time at the supranational level, is to be found in Art. 90 paras. 1 and 2 and Art. 91 para. 3. Their provisions concern the legal conditions as well as the limits of accession to the European Union, a legal entity based on the principle of subsidiarity itself: "The Republic of Poland may, by virtue of international agreements, delegate to an international organization or an international institution the competence of organs of State authority in relation to certain matters." If an international agreement ratified by the Republic of Poland constituting an international organization so provides, the laws it established by it shall be applied directly and have precedence in the event of a conflict of laws.

The principle of subsidiarity-the core and essence of a democratic and truly citizenfriendly State-has become a new constitutional principle in the Republic of Poland. In all its variety of meanings, it was even before this an excellent point of reference for appraisal of the legal and actual state of the country's systemic transformation. The conclusion emerges 
that constitutionalisation of that principle by way of a duty imposed on State authorities to observe it in all their actions of control should contribute to a fuller development of civil society and prevent arbitrariness on the part of the State machine. While, however, institutionalized and particularly judicial review of the observance of the principle of subsidiarity is common in the sphere of distribution of powers between the separate levels of public administration, it is difficult to find appropriate means and instruments of such review with respect to broader obligations that follow from that principle: this is shown by the force of the controversies and doubts as to the practice caused by the introduction of subsidiarity into the European Union treaties. ${ }^{17}$

That this is possible, however, is evidenced by the European Union's institutions, which, in spite of the controversies and practical problems that arise from the introduction of the subsidiarity principle into the Treaty on the European Union, have managed to work out a system of operationalizing the principle in a fairly effective way. The system requires every unit of the EU institutions involved in the law-making process to analyze drafts of new acts with regard to their conformity with the principle of subsidiarity, and now, pursuant to the provisions of the Lisbon Treaty, national parliaments of Member States are involved in the control of adherence to this principle. ${ }^{18}$ To a certain degree, a similar system of regular assessments of new bills with respect to the principle of subsidiarity results from the Regulatory Impact Assessment of governmental legislative bills and requirements set in the Rules of the Sejm requiring justification of all bills submitted to the Speaker of the lower chamber of the Parliament.

Work in the National Assembly has shown just how difficult a task it is to formulate the principle of subsidiarity for purposes of constitutional regulation. Hence, there is also a lack of precedents in the constitutional law of other countries, which have recognized its constitutional significance but have failed to introduce the provisions that would unequivocally define it (the above-mentioned federal clauses constitute an exception here). ${ }^{19}$ It is worth noting that Poland is bound by an instrument of international law that does define the principle of subsidiarity. This instrument is the European Charter of Local Self-

17 The legal definition of subsidiarity is contained in the Treaty on European Union (Art. 5.3): "Under the principle of subsidiarity, in areas which do not fall within its exclusive competence, the Union shall act only if and in so far as the objectives of the proposed action cannot be sufficiently achieved by the Member States, either at central level or at regional or local level,and can rather, by reason of the scale or effects of the proposed action, be better achieved by the Union."

18 See more: Overall Approach to the Application by the Council of the Subsidiarity Principle and Art. $3 b$ of the Treaty, European Council of Edinburgh -11-12 December 1992-Presidency Conclusions; Interinstitutional Agreement of October 25, 1993 between the European Parliament, the Council and the Commission on procedures for implementing the principle of subsidiarity; Keukleire, S.: The Principle of Subsidiarity between Word and Deed. Operationalization of Art. 3b of the Maastricht Treaty. In: De Groof, J.: Subsidiarity and Education. Leuven-Amersfoort, 1994; Ciavarini Azzi, G.: La Commission en matière du principe de subsidiarité. In: Hrbek, R. (ed.): Die Anwendung des Subsidiaritätsprinzips in der Europäischen Union. Baden-Baden, 1995, 59-69. See Winczorek, P.: Zasada subsydiarności w dyskusjach ustrojowych w Komisji Konstytucyjnej Zgromadzenia Narodowego [Principle of Subsidiarity in systemic debates in the Constitutional Committee of the National Assembly]. In: Subsydiarność [Subsidiarity]. Warszawa, 1996, 140-146.

19 See Winczorek, P.: Zasada subsydiarności w dyskusjach ustrojowych w Komisji Konstytucyjnej Zgromadzenia Narodowego [Principle of Subsidiarity in systemic debates in the Constitutional Committee of the National Assembly]. In: Subsydiarność [Subsidiarity]. Warszawa, 1996, 140-146. 
Government-Convention of the Council of Europe of 15 October, 1985, which in Art. 4, on the scope of activity of local government, recommends that the management of public affairs should generally speaking be the responsibility of authorities that are closest to the citizens, and that decisions going against that principle should take into account the scope and nature of the task, as well as considerations of efficiency and economy.

Attempts have also been made to define the principle of subsidiarity in legislative work in Poland. The initial guidelines for the draft law on activity of public benefit (a term used to describe non-governmental organizations) carried a formula that could have led to a related constitutional principle: "Activity of public benefit should be conducted in compliance with the principle of subsidiarity, consisting in that public authorities (government and local government) engage in direct operational activity in the field of public benefit only provided that:

(1) the obligation to engage in a particular kind of activity follows from existing regulations [...] or (2) the public tasks in this field are not adequately executed by nonpublic agents engaged in activity of public benefit." 20

During the proceedings of the National Assembly, an attempt was made to introduce the principle of subsidiarity into Chapter 1 of the draft in wording proposed by deputy Jerzy Ciemniewski ("The Republic of Poland protects voluntary individual and collective activity of the citizens within the field of implementing public goals, and restricts the social and economic functions of the State to activities indispensable for the implementation of the tasks of public authorities"). However, it ended in failure because it stressed the need to reduce the organizational and social welfare role of the State to a bare minimum. This proves that many who support including the principle of subsidiarity in the Constitution associate it with imposing an obligation upon the State to provide assistance to communities and individuals incapable of achieving their goals on their own, while at the same time they treat as marginal the idea of requiring such communities and individuals to undertake efforts to solve their problems relying on their own resources. This results from, among other things, the features of Polish society, where the prevalent attitude expects the State "to provide for the people", the ability to organize is rather poorly developed and efficient "intermediate levels" are very few.

It is worth stressing that introducing the principle into the Constitution was especially important with regard to the scope of State interventionism in the economy (cf. the formula used by an expert of the Constitutional Committee, Prof. Piotr Winczorek; "Public authorities should engage in only such kind of economic activity that cannot be independently undertaken by non-State economic entities and associations"). ${ }^{21}$ In one version of the constitutional draft (completed on 19 June, 1996), which did not envisage a preamble, the constitutional principle of the inviolability of ownership (providing for expropriation only for public purposes and only for adequate compensation) could have led to privatisation becoming illegal. That danger was avoided, while the Constitution in its Preamble contains the principle of subsidiarity, which also relates to the subsidiary character of the State's economic activity.

No doubt, the realization in constitutional law of the principle of subsidiarity is conducive to the development of civil society, one that is aware of its rights and duties and

20 Izdebski, H.: Fundacje i stowarzyszenia. Teksty i objaśnienia [Foundations and associations. Sources of law and explanation]. Warszawa, 1996, 177.

${ }^{21}$ Constitutional Committee of the National Assembly. Bulletin No. XIV, 74. 
able and willing to defend them, and also one that respects the rights and freedoms of others. On the other hand, though, the success and effectiveness of legal solutions inspired by that principle depends largely on citizens' civic maturity and political culture, e.g. on their willingness to compromise, respect for minority rights and so on. In countries that were deprived of democratic political practice for many decades, it is most important that those restructuring State and society should be guided by the postulates that together make up the principle of subsidiarity, yet achieving the full effect is bound to take time. For this reason introduction of the definition of the principle of subsidiarity into the Constitution would have been highly desirable.

Although created (at least by the groups that held the majority in the National Assembly, which decided on its adoption in the current version) with an assumption of juridicality, the Polish Constitution contains a large number of axiological references, especially in the Preamble. They enable us to decode the vision of the State assumed by the constitutional legislator, manifested in particular in the definition of the State as a special organization of society, built on the basis of certain principles, and locate it in the international context. In addition, the functioning of a society/community in the broadest sense, both inside and outside of the State, corresponds to the same assumptions: putting in first place the individual with his/her freedoms and rights and solidarity and cooperation in realising everything that is the common good at each stage of the organisation of human society.

Compared to the previous constitutional regulation, the currently applicable fundamental law contains many elements that are saturated with axiology. Before October 17, 1997, the basic norm determining the values upheld by the Republic of Poland was the then Art. 1 of Constitutional Provisions Maintained in Force, which provided that "the Republic of Poland shall be a democratic state ruled by law implementing the principles of social justice". From this principle, in its case law the Constitutional Court derived the axiological foundations of the relationship between the State and the individual in Poland, such as the right to life, right to trial, or right to privacy, as well as the principles of the functioning of the State organization: the supreme place of the Constitution in the system of laws, the autonomy of courts and impartiality of judges, the special role of a statute as the basic source of law, the operation of public authorities exclusively within the limits of, and pursuant to, the law, as well as the principle of non-abusive legislation, including prohibition of retroactive laws and the principle of protecting the citizen's trust in the State.

The constitutional regulation covers unequivocally and quite exhaustively the "component" principles of a state ruled by law, especially those relating to the rules governing the functioning of the state and its legal order. Therefore, the Constitutional Court has considered the principle of a state ruled by law, repeated in Art. 2 of the 1997 Constitution, as mainly an interpretation hint to assist in construing other norms (e.g. judgment $\mathrm{K}$ 28/97), and as an independent model for constitutional review where the Constitution did not offer sufficient regulations, for instance, with reference to the lawmaking principles (e.g., judgment K 10/98).

The principle of a democratic state ruled by law gained a new dimension in the new constitutional context. Both the notion of a "state ruled by law" and the "principles of social justice" it implemented must now be read through the lens of basic assumptions underlying the constitutional order in Poland and as implementing and protecting the set of values expressed in the Constitution. "Consequently, one cannot judge the respect for the principle 
of a state ruled by law without taking into account the values identified in the Preamble to the Constitution and neglecting the principle expressed in Art. 1 of the Constitution: that Poland is the common good of all its citizens" (judgment TK 8/98). The concept of justice expressly mentioned in the Preamble became, together with other values referred to there, one of the principles that everyone is to treat "as the unshakeable foundation of the Republic of Poland". Respect for these principles and values is also a duty on the part of the legislative power. In this context (the juxtaposition of Art. 1 and Art. 2 of the Constitution) the main focus is on the principle of justice understood as a factor conducive to fairness or, in other words, a just balance of the interests of the society as a whole (common good) and interests of an individual.

The Republic of Poland was defined, as early as in the first article, as "the common good of all its citizens" (a similar expression is used in the Preamble and in the context of citizens' duty of concern for the common good-Art. 82), and subsequently as a state ruled by law "implementing the principles of social justice" (Art. 2). "The inherent and inalienable dignity of the person" was recognized as the source of freedoms and rights of persons and citizens (Preamble and Art. 30), while the Constitution-the basic law for the State-was declared as based (among other things) on "social dialogue as well as on the principle of subsidiarity in the strengthening of the powers of citizens and their communities" (Preamble). Therefore, the definition of the Polish State in the Constitution refers to values typical of the Christian-democratic theory on the system of government (the social teaching of the Catholic Church).

Social dialogue, solidarity and subsidiarity should be, according to the letter of the Constitution, the basic tenets of the State's law-making activity. These values assume special importance in the situation, where the principles of the market economy have become solidified in a country, with all the related social costs, which are particularly onerous in a period of poor business trends and the impoverishment and marginalisation of large groups of the population.

However, the quite clear and consistent axiology of the Constitution is realised only to a limited extent in the contents of legislation or in the assessment of conformity of lowerranking instruments to the Constitution. There were sporadic, though increasingly frequent, cases in which the Constitutional Court based its judgments on this issue on the so-called "constitutional values", whereas applicants invoked them to support their theses as to the incompatibility of the challenged provisions with the more "specific" constitutional norms. This moderation is rooted in the opinion of the Constitutional Court that "constitutional values" are chiefly a starting place for interpreting other provisions of the Constitution. And so, the principle of subsidiarity is mainly referred to when elaborating on the interpretation of another constitutional principle, that of decentralization, while "common good" is used by the Court mainly to stress the interdependency between the rights of individuals and their duties to the whole of society, and the need to balance the interests of the individual and public interest. 